\title{
An Influence of Women on ASEAN Economic Growth
}

\author{
Adirek Vajrapatkul \\ School of Economic, Sukhothai Thammathirat Open University, Thailand \\ a.vajrapatkul@gmail.com
}

\begin{abstract}
Supported by the transition of the economy and the increasing of woman's ability and numbers, women have increasingly played a significant role in economic growth. As women have participated more in business and economic activities, they become a part of career and income creation and thus economic growth. Such causalities have been supported by some pieces of evidence produced by previous researches. However, some variables, missing from the previous works, still need to be investigated and confirmed in general. Thus in this work, we incorporated such variables in our study. To meet our objectives, we test the effect of 3 women related variables, namely labour force, life expectancy, and self-employment, on economic growth. We obtained the data of 10 ASEAN countries from the World Bank database which covers the period between 1994 and 2018. The effects of women related variables on economic growth were investigated by a panel regression technique. The results produced from the usual process and cointegration test revealed that the labour force and self-employment had a positive impact on economic growth, while life expectancy had a negative one which can be explained by the U-shape concept. Hence it comes to the suggestions that if the government expects to encourage economic growth, it needs to improve women life expectancy through public investment in women health and education, increase women self-employment by launching public projects for developing business relating skills, and prepare the business and economic environment to support women workforce participation.
\end{abstract}

Keywords: labour force; life expectancy; self-employment; panel data; cointegration. 


\section{Introduction}

In the past period, gender inequality was a primary issue in social, political, and economic development because it can directly affect social security, political stability, social wealth fare, income growth, and economic development. Various sources can cause discriminate in gender which produces further effects on participation in educations, works, and income-generating activities. Previously, the man was prioritized in the more advantageous position as they were perceived as a source of labour, leader, and family protector which support by, e.g., attributes of work available, social norm, culture, and religion.

In economic this gender inequality may be referred to as the market failure situation, caused by religious preference, regional factors, and civil freedom which can hinder the development of women in term of education and health that can subsequently affect negatively economic growth (Dollar \& Gatti, 1999).

Also, such inequality can be explained by the following approach. The ModernizationNeoclassical Approach which state that gender inequality is negatively associated with industrialization and economic growth. This inequality, e.g., in employment, wages, or vulnerability to poverty, results from human capital differentials, e.g., education and skills. Also, it indicates the crucial role of institution and culture in resolving this inequality. The Boserup Thesis and the WID Approach argues that there is a curvilinear relationship between economic growth and the status of women. The development of an urban economy leads to ' The polarization and hierarchization of men's and women's work roles. The initial stages of development result in a growing gap between men and women, other consequences of these changes, eventually lead to a reversal of this trend, i.e., the exclusion of women from the labour market results in tight labour markets and rising demand for female worker. In the development stage, women seek to acquire greater bargaining power. Critical Feminism and the GAD Approach argues that inequalities between men and women are shaped by institutional arrangements, e.g., patriarchal family structures, and discriminatory labour practices and property laws. Also, labour markets are gender discrimination, even when women have high 


\section{3rd International Conference on BUSINESS,}

\section{MANAGEMENT AND FINANCE \\ OXFORD, UNITED KINGDOM}

11-14 March, 2021

education. On the opposite, it argues that development will widen the gap between the incomes of men and women.

(Forsythe et al., 2000).

In the feminist literature which argued for gender inequality, they draw attention to the constraints posed by the structural distribution of rules, norms, resources, and inequalities of power. These constraints allocate men and women to different roles and responsibilities which result in variations in the gendered division of labour. The general assignment of primary responsibilities to men helps to explain higher male labour force participation rates, while most societies ascribe primary responsibility for unpaid reproductive labour to women. Feminist scholars have pointed to the growth that is defined by the value of goods and services that are bought and sold in the market place. The production of these goods and services are largely carried out by men. The goods and services produced through unpaid domestic labour for consumption and use by the family, largely done by women, are excluded from definitions of economic growth. This implies the exclusion of women for economic activity and growth (Kabeer, 2016).

Now it was recognized that the level of inequality between male and female have been reduced. The equality between them has been improved by the rising of the political and economic related freedom which allow male and female to choose activities and behave to develop themselves. Also, the technology, economic transition, and globalization facilitate both male and female to involve themselves in value-added activities which support their potential.

Regarding the above statements, women now become a crucial player in business and economic activities because they now have an equal opportunity in developing themselves in terms of education, health, and choice of works which will subsequently affect economic growth and development.

Motivated by the above discussion, we design this work to investigate the roles of women in spurring economic growth, i.e., workforce participation, life expectancy, and selfemployment. To meet our objective, we organize our work as follow. In the next Section, it will present the knowledge gained from some pieces of related literature. Section 3 will 


\section{3rd International Conference on BUSINESS,}

\section{OXFORD, UNITED KINGDOM}

highlight the methodology. The results and discussion will be conducted in Section 4. In Section 5, the policies for fostering economic growth will be proposed.

\section{Literature review}

In this section, we will summarize the concept and results from empirical studies related to the relationship between economic growth, female life expectancy, female labour force participation, and female self-employment. The detail for these relationships is as follow.

\subsection{An association between women life expectancy and economic growth}

Good health is a valuable asset of human. It is a part of human life that support his/her ability in conducting activities necessary for achieving various desires. Not only at the individual level, but the issue of good health has also been globally recognized and it was set as an ultimate target of development agenda, e.g., Sustainable Development Goals (SDGs) which is a vision for 2030 that target to improve people health status to promote world economic growth (Alhassan et al., 2020).

To indicate an improvement in the health status of people in general, several indicators have been used both individually and compositely. At the individual term, crude death rate, proportional mortality rate, infant mortality rate, maternal mortality rate, and life expectancy, for instance, have been used for that purpose. However, life expectancy is commonly used, especially, in the research area as it implies positive aspects of economic accumulations, growths, and developments.

Regarding this life expectancy, which indicates the extension of people life, now people can raise the level of this indicator as they have been supported by, e.g., an improvement in medical technology and the new health-conscious living styles. Also, increasing in education 


\section{3rd International Conference on BUSINESS,}

\section{MANAGEMENT AND FINANCE \\ OXFORD, UNITED KINGDOM}

11-14 March, 2021

participation and labour force have supported such an improvement of life expectancy level, particularly in the female group. Nevertheless, some activities and behaviours, e.g., factories and military services, drive, smoke, and alcohol drinking, have deteriorated that level, particularly in the male group (Mahumud et al., 2013). An improvement in life expectancy which reflects an improvement in human capital has expanded the knowledge, skill, and wealth accumulation process of individuals because when they aware of their longer life, they will incline to invest more in education which leads them to gain more productivity and ability to create work which are crucial sources of income (Ngangue \& Manfred, 2015). Also, at the country level, investments in the health system, which expand life expectancy, will contribute to economic outputs through increasing of, e.g., employment in the health sector, social protection, social cohesion, equality which can lead to a productive society and growth (Yildirim \& Calıskan, 2020).

The association between life expectancy and economic growth may be implied from the following two hypotheses, i.e., the absolute income hypothesis and the contextual hypothesis also called the Wilkinson hypothesis. The absolute income hypothesis asserts that health is a nonlinear concave function of income, so income increases produce diminishing returns of health. In contrast, the contextual hypothesis, or the Wilkinson hypothesis, postulates a contextual and impact of income on the health of individuals which can be inferred that an improvement in material conditions plays an important role in determining individual health, particularly in developed countries (Luo \& Xie, 2020). Although these two hypotheses discuss the effect of income on health, the association between health and income can be explained in the reverse direction.

Although the life cycle theory states the life expectancy as a critical factor that positively affects the accumulation of saving and human capital, it can simultaneously produce negative effects on economic growth (He \& Li, 2020). Especially, when the government overinvest in the health system to improve, e.g., health status and life expectancy of citizen and such investment can cause a reduction in other investments that benefit economic growth (Ngangue \& Manfred, 2015). Also, increased life expectancy might harm a growth in income per capita, if it accelerates population growth, especially in the countries that undergo the demographic transition (Cervellati \& Sunde, 2011). 


\section{3rd International Conference on BUSINESS,}

\section{MANAGEMENT AND FINANCE \\ OXFORD, UNITED KINGDOM}

11-14 March, 2021

The empirical studies showed that life expectancy is a fundamental determinant of economic growth (Ecevit, 2013); life expectancy affects economic growth positively in developing countries but condition by the level of income of these countries (Ngangue \& Manfred, 2015); population health proxied by life expectancy exert a positive and significant effect on both real income per capita as well as growth (Sharma, 2018); increase in life expectancy increases economic growth (Alhassan et al., 2020); life expectancy of countries with higher health status had no significant impact on economic growth. However, the increase in the life expectancy of countries with lower health status influenced economic growth positively (Yildirim \& Calıskan, 2020); there are significantly positive long-run relationships between life expectancy and GDP per capita, but the positive impact of life expectancy on economic growth is stronger in the group with a higher level of ageing $(\mathrm{He} \& \mathrm{Li}, 2020)$. In the case of female, a work showed that at time of higher rate of life expectancy of females relative to males, the GDP per capita was increased (Mahumud et al., 2013).

The empirical works of the inverse direction between life expectancy and economic growth show that the shape of the relationship between life expectancy and economic growth is represented by convexity for a low level of life expectancy and concavity for large high values (Azomahou et al., 2009); increase in life expectancy may lead to negative effects on income per capita growth before the demographic transition, i.e., when life expectancy increases population growth, while the positive effect of life expectancy may exist when fertility rates reduce (Cervellati \& Sunde, 2011); the countries which obtained a higher growth rate of life expectancy experienced a lower growth rates of GDP per capita (Hansen \& Lønstrup, 2015); increases in life expectancy could not raise income per capita, as there were the nonlinear effects and the diminishing effects of life expectancy on income per capita (Okunade \& Osmani, 2020).

According to these literature, although they discovered an association between the overall life expectancy, not gender specific, and economic growth, we are motivated to test the following hypothesis.

Hypothesis 1: Women life expectancy has a significant positive effect on economic growth 


\section{3rd International Conference on BUSINESS,}

\section{MANAGEMENT AND FINANCE \\ OXFORD, UNITED KINGDOM}

11-14 March, 2021

\subsection{An association between the women labour force and economic growth}

In the production function, an ingredient that vitally determines the level of output is the labour supply which behaves positively to such quantity of output. Inferring from the role of labour in the production function, we can state a crucial role of the labor force, commonly proxied by labour participation rate, in determining output growth and development within our economy.

Previously the quantity of labour force was mostly determined by the male population. However after technology progress, education opportunity expands, work-related skills have been changed, and perceptions on women role have been altered, such quantity of labour force has increasingly been determined by the population of the female. Especially, in the developed countries, women who previously worked in the informal labour market have begun to work for the paid works in the formal market (Doğan \& Akyüz, 2017). The phenomena of increasing in women workforce participation in those developed countries can be explained by economic conditions which determine the kind of work and the need for the female labour force, education systems, families care burdens, gender ideologies (Besamusca et al., 2015), social norms, fertility rates, and access to childcare and other supportive services (Kumari, 2018).

Although the rate of woman workforce participation can rise in the developed country, there exists an evidence base relationship between woman workforce participation and economic development that express in the U-shape manner, knowing as the U-shape hypothesis. According to this hypothesis, it states that at the beginning of economic development, where the economy was dominated by the agriculture sector, many women participated in the labour force by working in their family farms or by creating household businesses. As an economy undergoes structural changes and transit from agriculture to industry, women's labour force participation rates tend to fall because they were unable to take advantage of work opportunities in formal and industrial sectors. This stage also delays women's entry into the labour market as they enrol for education. In later stages of economic development where female education increases, fertility rates decline, and socio-cultural attitudes evolve, their rate of workforce participation increases. In the development stage, the emergence of white-collar sectors provides new employment opportunities for women (Chapman, 2015) (Kumari, 2018). However, some countries do not exhibit this U-shaped 


\section{3rd International Conference on BUSINESS,}

\section{MANAGEMENT AND FINANCE \\ OXFORD, UNITED KINGDOM}

11-14 March, 2021

relationship because of the effect of social norms, and the nature of economic growth, and job creation (Verick, 2018).

In the empirical studies, they found that there is no relationship between the level of economic development and women's participation rates in the labour force. That is the growth by itself is not sufficient to increase women's economic activity and labour force participation, especially in the case of the growth of the country that leads by a particular sector that women can not participate (Lahoti \& Swaminathan, 2013); the participation rates of young and older women are partly explained by sector sizes and the level of economic development. However, the labour force participation rates of women in the workforce group were explained by families and gender ideologies, education, and religious (Besamusca et al., 2015); female labour force participation is an important driver of growth and development. The participation of women is the outcome of various economic and social factors, e.g., poverty and education (Verick, 2018); female labour force participation has short-run positive significant effects on economic development but adverse effects in the long run (Haque et al., 2019); There was a long-run relationship between labour force participation, gross fixed capital formation, and Real GDP (Yakubu et al., 2020). For the U-shape hypothesis, the empirical studied found that there exists a U-shaped relationship between female labour force participation and economic growth (Lechman, 2014). Moreover, the U-shaped feminization hypothesis was not positively verified in the case of low-income countries (Lechman \& Kaur, 2015); there is a U-shaped relationship between economic growth and female labour force participation rates and a low female labour force participation rates can be explained by the transition towards the bottom of the U-shaped curve (Chapman, 2015); economic growth increases women's labour force participation rate first but then it decreases women's labour force participation rate which indicates a reverse $U$ relationship between economic growth and female labour force participation (Doğan \& Akyüz, 2017). To test the effect of women workforce participation on economic growth, we propose the following hypothesis.

Hypothesis 2: Women labour force has a significant positive effect on economic growth 


\section{3rd International Conference on BUSINESS,}

\section{MANAGEMENT AND FINANCE \\ OXFORD, UNITED KINGDOM}

11-14 March, 2021

\subsection{An association between women self-employment and economic growth}

Economic crisis often leads individuals to go into business by pushing them toward selfemployment. In that circumstance, the business visionaries or independently employed individuals, who can observe the opportunities and can combine the factors of production, will become a potential player in driving the economic out of such crisis (González-Sánchez et al., 2020). On one hand, self-employment can be seen as a solution for individuals who fail from acquiring a job from the formal market and hence they design to choose this self-employed channel as their last resort for gaining revenues (Matejovsky et al., 2014), on the other, selfemployment can be seen as a valuable choice for creating business and income. Even though there exists a question of whether or not self-employment has any benefit for the economy regarding income generation, it can, at least, give a non-market value of feeling one's own boss (Goetz et al., 2012). To clarify why people choose self-employment as a choice, two hypotheses were proposed. The first hypothesis is the push hypothesis which states that unemployed people become self-employed because they faced the situation of labour market collapse. In this circumstance, individuals will take self-employment as a last resort for income generation. The second hypothesis is the pull hypothesis. This hypothesis holds that people become self-employed in light of economic growth. In such a growth condition, people pick self-employed as it offers new business opportunity, carrier, and income (Rene Caceres \& Ann Caceres, 2017). Other than the economic circumstance that clarifies the reason for selfemployed, several elements that can fundamentally influence the choice to go into selfemployed include, e.g., level of education and training (Carpenter \& Loveridge, 2017).

Although some empirical studies revealed a negative association between self-employment and income growth(Acs et al., 1994) (Barros \& Pereira, 2008), others confirmed that selfemployment has positive impacts not only on income growth (Carpenter \& Loveridge, 2017) (González-Sánchez et al., 2020) but also poverty reduction (Goetz et al., 2012), and regional development (Matejovsky et al., 2014). The factors that may cause uncorrelated motion between self-employment and income growth are, e.g., geographic location and education, race, age, and gender (Willis et al., 2020). 


\section{3rd International Conference on BUSINESS,}

\section{MANAGEMENT AND FINANCE \\ OXFORD, UNITED KINGDOM}

In the women-specific case, it found that female-owned businesses are one of the fastestgrowing entrepreneurial populations (Bögenhold \& Klinglmair, 2015). However compare to man, women face various obstacles, e.g., family responsibilities that have to be managed to give them access to the same opportunities as men (Bögenhold \& Klinglmair, 2015) and nationality discrimination in the entrepreneurial activities of women. Also, the effect of education on the probability of self-employment differs significantly between men and women. In the case of women, e.g., secondary education is a less likely contribution to women in starting a business, whereas it contributes to man (Rico \& Cabrer-Borrás, 2018). For the factor that supports an increase in women self-employment, a study found that intra-sectoral developments were one significant factor, especially women self-employment within trade and culture sectors (van Es \& Van Vuuren, 2011). Inferring to the general relationship between self-employment and the growth of the economy discussed above, we write the following hypothesis.

Hypothesis 3: Women self-employment has a significant positive effect on economic growth

\section{Methodology}

To test our hypotheses, we employ the data from the World Bank database from 1994 to 2018. Therefore with 10 ASEAN countries, we have 250 observations under a balanced data dataset (Asteriou \& Hall, 2007). For the variables used in this study, we use GDPG, LF, LE, and SEF to denote the growth rate of gross domestic product, female labour force as $\%$ of the total labour force, female life expectancy at birth as a number of years, and female self-employed as $\%$ of female employment, respectively (World Bank, 2021).

Before analyzing the obtained data, we tried to clean the data and checked the basic assumptions to avoid inaccurate results. Nevertheless, the linear regression assumptions testing may not necessarily to be conducted in panel data analysis because one of the benefits of panel data analysis is that it can handle better with the issue coming from violations of regression assumptions (Stock \& Watson, 2015). 


\section{3rd International Conference on BUSINESS,}

\section{MANAGEMENT AND FINANCE}

\section{OXFORD, UNITED KINGDOM}

As panel data combine the time-series with cross-sectional data, the panel data analysis become an effective tool to handle this data type. In this research context, we can express a combination between $n$ different observed entities and $T$ different periods (Stock \& Watson, 2015) by the following equation:

$$
Y_{i t}=f\left(X_{i t}\right) \text {, }
$$

where $i=1,2, \ldots, n$ represents the country variety and $t=1,2, \ldots, T$ is the time interval.

Here, we can write a simple linear panel data model with one explanatory variable as follows:

$$
Y_{i t}=\alpha+\beta X_{i t}+u_{i t}
$$

Regarding the country-specific factors, we thus need to consider the properties of the fixed effects and the random-effects model. For the fixed effects model, which is also known as the least-squares dummy variables (LSDV) model, where each entity is constant over time but differ across entities, i.e., allows for different constants $\alpha_{i}$ for each group (Stock \& Watson, 2015). So we can show the fixed effects model as:

$$
Y_{i t}=\alpha_{i}+\beta X_{i t}+u_{i t}
$$

For the random-effects model, this model treats the constants $\alpha_{i}$ for each section as random parameters (Greene, 2012). Therefore, this model can be represented by:

$$
Y_{i t}=\alpha_{i}+\beta X_{i t}+u_{i t}
$$

where $\alpha_{i}=\alpha+v_{i}$ and $v_{i}$ is a zero-mean standard random variable.

By extending the simple panel data model to cover all variables in this work, we write the following model:

$$
D G D P G_{i t}=\alpha+\beta_{1} D L E_{i t}+\beta_{2} D L F_{i t}+\beta_{3} D S E F_{i t}+\varepsilon_{i t},
$$

To choose between fixed and random effect model, we use the usual technique, i.e., Hausman test (Hausman, 1978). 


\section{3rd International Conference on BUSINESS,}

\section{MANAGEMENT AND FINANCE}

OXFORD, UNITED KINGDOM

\section{Result and Discussion}

Before testing our hypotheses, we present the movement of all variables of 10 ASEAN countries in Fig. 1. Although we can guess the direction of the association between variables within Fig. 1, it should be more confident if we check it under the condition of stationary data.

Figure 1: the movement of gross domestic product growth, female labor force, female life expectancy, and female self-employed of 10 ASEAN countries.
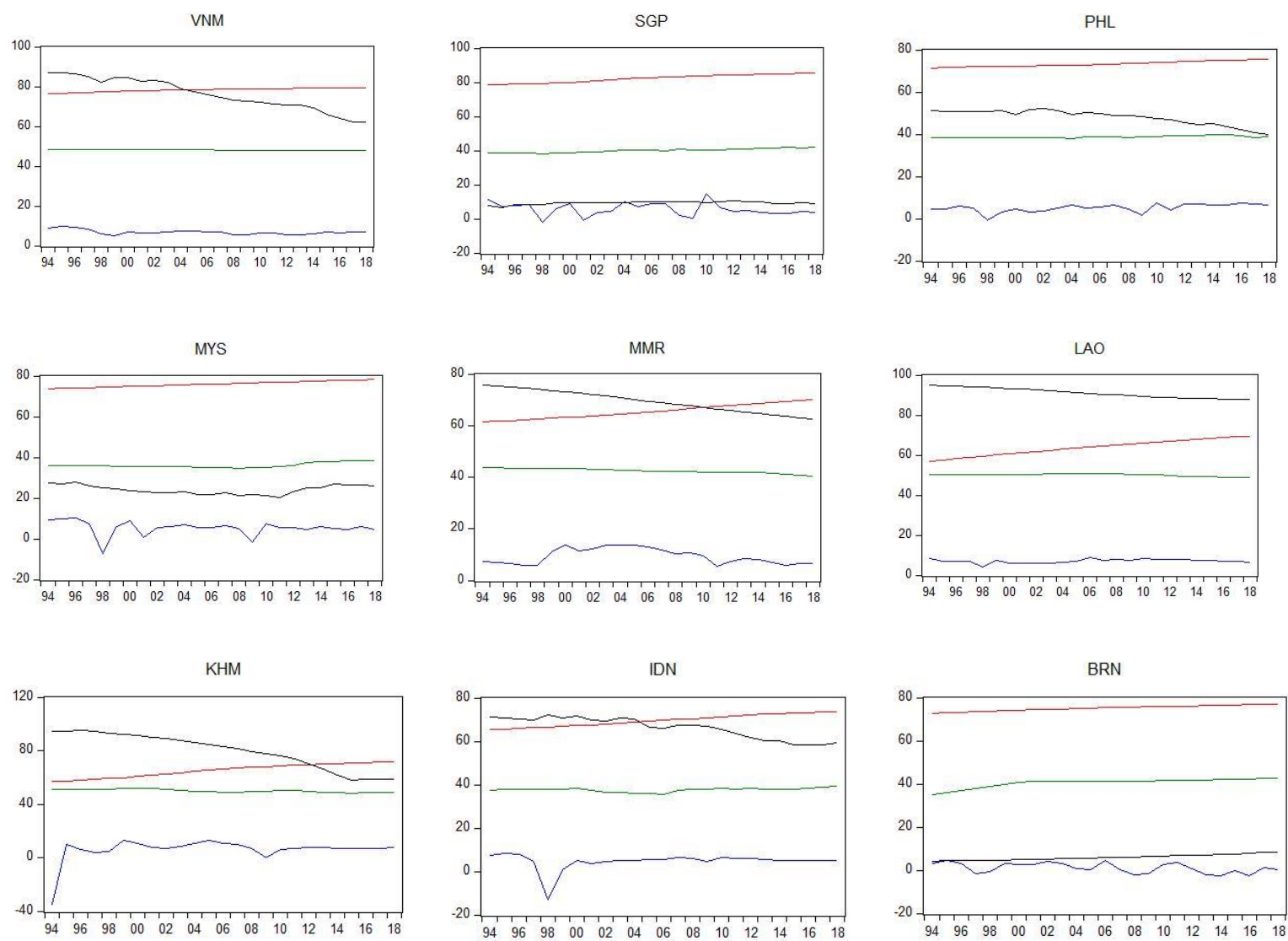
3rd International Conference on BUSINESS,

MANAGEMENT AND FINANCE

OXFORD, UNITED KINGDOM

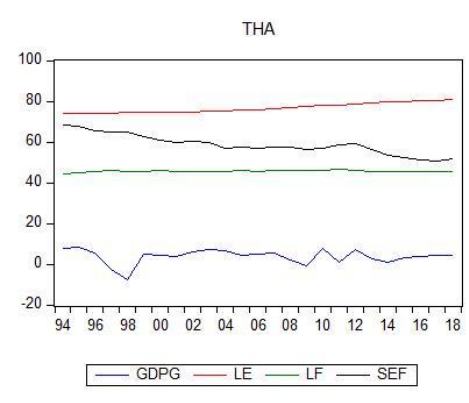

Source: Author' presentation

To satisfy the data stationary condition, we manipulate all variables by first-order differencing and conduct the unit root test. Based on the three test statistics for each variable showed in Tab. 1, we can state that the stationary condition is satisfied.

Table 1: Panel Unit root test for the first- order differencing variables

\begin{tabular}{llll}
\hline $\begin{array}{l}\text { Variables/Unit } \\
\text { root test }\end{array}$ & LLC & Fisher-ADF & Fisher-PP \\
\hline DGDPG & $-4.40760^{* * *}$ & $69.6367^{* * *}$ & $76.3938^{* * *}$ \\
DLE & $-9.61424^{* * * *}$ & $105.259^{* * *}$ & $128.658^{* * *}$ \\
DLF & $-2.03678^{* *}$ & $43.3760^{* * *}$ & $75.7757^{* * *}$ \\
DSEF & $-1.49518^{* *}$ & $40.1684^{* * *}$ & $78.1567^{* * *}$ \\
\hline
\end{tabular}

*** denotes significance at the $1 \%$ level

Source: Author' calculation

Next, we decide whether a fixed effect or random effect model is appropriated for testing our hypotheses. For this purpose, we conduct Hausman specification test. Tab. 2 demonstrates the result and it shows that the p-value is 0.9024 which is larger than 0.05 (5\% significance level). Consequently, this implies that the random-effects model is appropriated. 


\section{3rd International Conference on BUSINESS,}

OXFORD, UNITED KINGDOM

Table 2: Hausman specification test

\begin{tabular}{lccc}
\hline Test Summary & $\begin{array}{r}\text { Chi-Sq. } \\
\text { Statistic }\end{array}$ & $\begin{array}{r}\text { Chi-Sq. } \\
\text { d.f. }\end{array}$ & Prob. \\
\hline $\begin{array}{l}\text { Cross-section } \\
\text { random }\end{array}$ & 0.573744 & 3 & 0.9024 \\
\hline
\end{tabular}

Source: Author' calculation

Now the results of panel data analysis with random effects model are summarized in Tab. 3. According to Tab. 3, it demonstrates that DLE and DSEF are significantly and positively affect DGDP, whereas, DLF is significantly and negatively affect DGDPG. Also, based on Cointegration test by Johansen-Fisher Panel Cointegration Test (Stojkoski et al., 2017) represented in Table 4, it indicated the long-run relationship between DLE, DLF, DSEF and DGDP.

Table 3: Random effects model, DGDPG as dependent Variable

\begin{tabular}{lc}
\hline Variables & Coefficients \\
\hline DLE & $0.91^{* * *}$ \\
DLF & $-0.78^{* *}$ \\
DSEF & $0.21^{* * *}$ \\
R-squared & 0.256 \\
Prob(F-statistic) & 0.000 \\
Durbin-Watson stat & 0.94 \\
*** & denotes significance at the 5\% level, * denotes significance at the $10 \%$
\end{tabular}

level

Source: Author' calculation 


\section{3rd International Conference on BUSINESS,}

MANAGEMENT AND FINANCE

OXFORD, UNITED KINGDOM

Table 4: Johansen-Fisher Panel Cointegration Test

\begin{tabular}{|c|c|}
\hline & Statistic \\
\hline \multicolumn{2}{|c|}{ within-dimension } \\
\hline Panel v-Statistic & -0.271757 \\
\hline Panel rho-Statistic & $-3.550778^{* * *}$ \\
\hline Panel PP-Statistic & $-9.653915^{* * *}$ \\
\hline Panel ADF-Statistic & $-9.217752^{* * *}$ \\
\hline \multicolumn{2}{|c|}{ between-dimension } \\
\hline Group rho-Statistic & -0.422151 \\
\hline Group PP-Statistic & $-9.056846^{* * *}$ \\
\hline Group ADF-Statistic & $-6.461629^{* * * *}$ \\
\hline
\end{tabular}

$* * *$ denotes significance at the $1 \%$ level

Source: Author' calculation

What we discovered from the results of the analysis presented in Tab. 3 and Tab. 4 are that women life expectancy and self-employment positively affected the growth rate of gross domestic product. Nevertheless, women workforce participation affected that rate negatively. That is if women life expectancy was increased by one year, it would induce additional $0.91 \%$ growth in GDP. Similarly, if women self-employment was risen by $1 \%$, it would add $0.21 \%$ more to GDP growth rate. However, $1 \%$ increased in the women labour force would force $0.78 \%$ of GDP growth rate down.

Straightforwardly, an association between women life expectancy and GDP growth rate can be explained by what we summarized in the literature review Section, i.e., when individuals live longer they may willing to invest more in educations and assets to improve their human capital and physical capital which benefit their ability to generate income and wealth which in turn benefit for economic growth. Likewise, increasing the number of women self-employment can bring growth to our economy but the reason support this association may line in a simple following logical flow. That is when women design to choose self-employment as their income generation tool and such self-employed business can offer them at least zero profit which calculated from the opportunity cost framework, it is activating the resources within the 


\section{3rd International Conference on BUSINESS,}

\section{MANAGEMENT AND FINANCE \\ OXFORD, UNITED KINGDOM}

11-14 March, 2021

economy, i.e., labour, capital, land, and entrepreneurship, to work. Therefore when resources are utilized effectively they will generate income and growth in our economy. Nevertheless, as discussed in previous literature, the growth resulted from an increase in women selfemployment may be reversed if those self-employment produce less income than what produced from full-time formal employment. Therefore, the primary conditions that will guarantee the positive effect of women self-employment on economic growth include, e.g., women ability, business environment, and support from related agents. The negative association between women workforce participation and economic growth may be explained by the implication of the bidirectional relationship and the U-shape hypothesis. The implication for the bidirectional relationship allows us to assume both the effect of women workforce participation on the GDP growth and the effect of GDP growth on women workforce participation. Based on the U-shape hypothesis which states that in a particular period of economic progress, it will bring down the woman workforce participation rate as in this period, women attend more education. Here, one might interpret that the reduction of women workforce participation will lead to economic progress, which must have a growth attribute within its composition, and vice versa. However, if this is the case, in the subsequent periods after women are ready, their workforce participation should come along with the growth of the economy.

\section{Policy Recommendation}

From the results of the analysis, we propose the following recommendations to related government agents who are in charge of encouraging economic activities and growth by continuously 1) improving women life expectancy which may be succeeded through public investment in women health and education and elimination of the related factors that prevent women to access to that health and education improvement, e.g., poverty and, 2) increasing women self-employment which can be achieved by launching the public projects for developing skills relating to creative thinking, research, production, negotiation, and marketing, 3) preparing the business and economic environment to support women workforce participation which may be attained by linking the womenwork-related attributes and skills to 


\section{3rd International Conference on BUSINESS,}

\section{MANAGEMENT AND FINANCE}

\section{OXFORD, UNITED KINGDOM}

the labor market, investing in technology that facilitates women work participation and reducing discrimination related to gender.

\section{Conclusion}

This work was conducted to study the impacts of three variables, life expectancy, workforce participation, and self-employment of women, on economic growth. These 3 variables were selected by concerning their potential impacts on economic growth. We test our hypotheses by using panel data obtained from the World Bank database. The data of 10 ASEAN countries were collected and manipulated by first-order differencing to make them fit with the primary condition of data stationary. We then processed to choose an appropriate model which lead to the use of the random effect model. Also, we test for the cointegration of the panel data. After the analysis, we discovered that life expectancy and self-employment of women had a positive effect on and long term relationship with GDP growth, whereas the workforce participation showed a negative relationship with that growth. Hence, improving women life expectancy, increasing women self-employment, and investing in the business and economic environment that support women workforce participation, were the policy recommendations that we proposed.

\section{Acknowledgements}

This research is supported by the school of economics, Sukhothai Thammathirat Open University (STOU), Thailand. This work is also supported by the Department of Economics, The University of Central Thailand (UCT), Thailand. 


\section{3rd International Conference on BUSINESS,}

MANAGEMENT AND FINANCE

11-14 March, 2021

OXFORD, UNITED KINGDOM

\section{Reference}

Acs, Z. J., Audretsch, D. B., \& Evans, D. S. (1994). Why does the self-employment rate vary across countries and over time? CEPR Discussion Papers.

Alhassan, G. N., Adedoyin, F. F., Bekun, F. V., \& Agabo, T. J. (2020). Does life expectancy, death rate and public health expenditure matter in sustaining economic growth under COVID- 19: Empirical evidence from Nigeria? Journal of Public Affairs, e2302.

Asteriou, D., \& Hall, S. G. (2007). Applied Econometrics: A modern approach, revised edition. Hampshire: Palgrave Macmillan, 46(2), 117-155.

Azomahou, T. T., Boucekkine, R., \& Diene, B. (2009). A closer look at the relationship between life expectancy and economic growth. International Journal of Economic Theory, 5(2), 201-244.

Barros, A. A. de, \& Pereira, C. M. M. de A. (2008). Empreendedorismo e crescimento econômico: Uma análise empírica. Revista de Administração Contemporânea, 12(4), 975-993. https://doi.org/10.1590/S1415-65552008000400005

Besamusca, J., Tijdens, K., Keune, M., \& Steinmetz, S. (2015). Working women worldwide. Age effects in female labor force participation in 117 countries. World Development, $74,123-141$.

Bögenhold, D., \& Klinglmair, A. (2015). Female Solo Self-Employment-Features of Gendered Entrepreneurship. International Review of Entrepreneurship, 13(1).

Carpenter, C. W., \& Loveridge, S. (2017). Immigrants, Self-Employment, and Growth in American Cities. 10.

Cervellati, M., \& Sunde, U. (2011). Life expectancy and economic growth: The role of the demographic transition. Journal of Economic Growth, 16(2), 99-133.

Chapman, K. A. (2015). Economic development and female labor force participation in the Middle East and North Africa: A test of the U-shape hypothesis. Gettysburg Economic Review, 8(1), 3 .

Doğan, B., \& Akyüz, M. (2017). Female labor force participation rate and economic growth in the framework of kuznets curve: Evidence from Turkey. Review of Economic and Business Studies, 10(1), 33-54. 


\section{3rd International Conference on BUSINESS,}

\section{OXFORD, UNITED KINGDOM}

Dollar, D., \& Gatti, R. (1999). Gender inequality, income, and growth: Are good times good for women? (Vol. 1). Development Research Group, The World Bank Washington, DC.

Ecevit, E. (2013). The impact of life expectancy on economic growth: Panel cointegration and causality analyses for OECD countries. The International Journal of Social Sciences, $16(1), 1-14$.

Forsythe, N., Korzeniewicz, R. P., \& Durrant, V. (2000). Gender inequalities and economic growth: A longitudinal evaluation. Economic Development and Cultural Change, 48(3), 573-617.

Goetz, S. J., Fleming, D. A., \& Rupasingha, A. (2012). The Economic Impacts of SelfEmployment. Journal of Agricultural and Applied Economics, 44(3), 315-321. https://doi.org/10.1017/S1074070800000432

González-Sánchez, V. M., Martínez Raya, A., \& de los Ríos-Sastre, S. (2020). An Empirical Study for European Countries: Factors Affecting Economic Growth and SelfEmployment by Gender. Sustainability, 12(22), 9450. https://doi.org/10.3390/su12229450

Greene, W. H. (2012). Econometric Analysis 7th ed (International).

Hansen, C. W., \& Lønstrup, L. (2015). The rise in life expectancy and economic growth in the 20th century. The Economic Journal, 125(584), 838-852.

Haque, A. U., Kibria, G., Selim, M. I., \& Smrity, D. Y. (2019). Labor force participation rate and economic growth: Observations for Bangladesh. International Journal of Economics and Financial Research, 5(9), 209-213.

Hausman, J. A. (1978). Specification tests in econometrics. Econometrica: Journal of the Econometric Society, 1251-1271.

He, L., \& Li, N. (2020). The linkages between life expectancy and economic growth: Some new evidence. Empirical Economics, 58(5), 2381-2402.

Kabeer, N. (2016). Gender equality, economic growth, and women's agency: The "endless variety" and "monotonous similarity" of patriarchal constraints. Feminist Economics, 22(1), 295-321. 


\section{3rd International Conference on BUSINESS,}

\section{OXFORD, UNITED KINGDOM}

Kumari, R. (2018). Economic growth, disparity, and determinants of female labor force participation. World Journal of Entrepreneurship, Management and Sustainable Development.

Lahoti, R., \& Swaminathan, S. (2013). Economic growth and female labour force participation in India (Working Paper No 414). Bangalore: Indian Institute of Management Bangalore.

Lechman, E. (2014). Female Labor Force Participation and Economic Growth. ReExamination of U-Shaped Curve. Re-Examination of U-Shaped Curve.(March 16, 2014).

Lechman, E., \& Kaur, H. (2015). Economic growth and female labor force participationverifying the U-feminization hypothesis. New evidence for 162 countries over the period 1990-2012. New Evidence For, 162, 1990-2012.

Luo, W., \& Xie, Y. (2020). Economic growth, income inequality and life expectancy in China. Social Science \& Medicine, 256, 113046.

Mahumud, R. A., Rawal, L. B., Hossain, G., Hossain, R., \& Islam, N. (2013). Impact of Life Expectancy on Economics Growth and Health Care Expenditures: A Case of Bangladesh. Universal Journal of Public Health, 1(4), 180-186.

Matejovsky, L., Mohapatra, S., \& Steiner, B. (2014). The Dynamic Effects of Entrepreneurship on Regional Economic Growth: Evidence from Canada: Entrepreneurship Dynamics. Growth and Change, 45(4), 611-639. https://doi.org/10.1111/grow.12055

Ngangue, N., \& Manfred, K. (2015). The impact of life expectancy on economic growth in developing countries. Asian Economic and Financial Review, 5(4), 653.

Okunade, A. A., \& Osmani, A. R. (2020). Effects of life expectancy on economic growth: New results using the flexible Box-Cox power transformation model. Applied Economics Letters, 27(20), 1681-1684.

Rene Caceres, L., \& Ann Caceres, S. (2017). Self-employment in Latin America. The Journal of Developing Areas, 51(3), 33-49. https://doi.org/10.1353/jda.2017.0059

Rico, P., \& Cabrer-Borrás, B. (2018). Gender differences in self-employment in Spain. International Journal of Gender and Entrepreneurship. 


\section{3rd International Conference on BUSINESS,}

\section{MANAGEMENT AND FINANCE}

OXFORD, UNITED KINGDOM

Sharma, R. (2018). Health and economic growth: Evidence from dynamic panel data of 143 years. PloS One, 13(10), e0204940.

Stock, J. H., \& Watson, M. W. (2015). Introduction to econometrics.

Stojkoski, V., Popova, K., \& Tevdovski, D. (2017). Financial Development and Growth: Panel Cointegration Evidence from South-Eastern and Central Europe.

van Es, F., \& Van Vuuren, D. (2011). A decomposition of the growth in self-employment. Applied Economics Letters, 18(17), 1665-1669.

Willis, D. B., Hughes, D. W., Boys, K. A., \& Swindall, D. C. (2020). Economic growth through entrepreneurship: Determinants of self- employed income across regional economies. Papers in Regional Science, 99(1), 73-95. https://doi.org/10.1111/pirs.12482

World Bank. (2021). International Development, Poverty, \& Sustainability [Text/HTML]. World Bank. https://www.worldbank.org/en/home

Yakubu, M. M., Akanegbu, B. N., \& Jelilov, G. (2020). Labour force participation and economic growth in Nigeria. Advances in Management and Applied Economics, 10(1), $1-14$.

Yildirim, D. C., \& Calıskan, H. (2020). The influence of health on economic growth from the perspective of sustainable development: A case of OECD countries. World Journal of Entrepreneurship, Management and Sustainable Development. 